\title{
Mass Media and Ideology Dissemination against Democracy in Thailand
}

\author{
SONGYOT BUAPHUEAN \\ Committee and Secretary of Innovative Political Communication Program \\ Department of Communication Arts Faculty of Humanities and Social Sciences, Burapha University, Thailand \\ email: songyot_b@yahoo.com
}

\begin{abstract}
The study on Mass Media and Ideology Dissemination against Democracy in Thailand is qualitative study with the method of documentary research from text books, books, newspapers and online newspapers to find the definition of democracy which was the system of forming the elected government with the principle of sovereignty, majority, equality, freedom and laws. However, some mass media had false consciousness of democracy which included: election brought bad quality politicians; recruitment of persons to form the government was better than election; promotion of superstition; one man one vote was not for Thai society; capitalism deteriorated the nation; The Armed Forces worked for the people. Another concept was the idea that believed Thai society was praising the elite groups. The ideology said the society should obey the senior citizen who had morals, and the Armed Forces forced people to obey.
\end{abstract}

Keywords: mass media, democracy, ideology dissemination

\section{Introduction}

Democracy has been well accepted world-wide because democracy believes all people possess the sovereignty. They are the ones who elect their own representatives as once the former US President, Abraham Lincoln delivered his speech-"Democracy is the government of the people, by the people, for the people." All the administrators must realize that the supreme power come from the people, and these people elect all the administrators to work. All the power must be used to serve the people, and to promote people's right, freedom, equality, and fairness. Accordingly, democracy allows people to gain freedom of seeking for information and use the information to make political decision. Then the decision gives the benefits back to the people.

Mass media is responsible for reporting and publicizing all events incur in the society, expressing its opinions, and criticizing social problems. In addition, all media's reports become historical evidence for people to research what have happened. Newspaper is a kind of mass media which takes many different roles for example as a medium in the communication between a government and its people, as a knowledge provider for people, as a watchdog who monitors the government's administration. Also, in some circumstances, the newspaper collaborates with the government to develop the society. At this point, the newspaper must watch its steps carefully as its collaboration might be mistakenly assumed that the newspaper is the government's mouthpiece rather than the protector of public benefits

Armand Mattelart and Michele Mattelart 1998,p.29 (Mattelart, p.29, 1998) cited from Buaphuen Songyot, 2557 p. 82 stated that newspaper was in charge of presenting to and watching the society-a watch dog. It reported what happened in the society. Second, it publicized activities incurred in the society. It also explained the relation among institutes, organizations, and groups. Third,

Received: March 02, 2017, Revision: April 13, 2017, Accepted: May 19, 2017

Print ISSN: 0215-8175; Online ISSN: 2303-2499.

Accredited by DIKTI. SK Kemendikbud, No.040/P/2014, valid 18-02-2014 until 18-02-2019, Indexed by DOAJ 
the newspaper passed on cultural heritages to the society by presenting core cultures and promoting good social values. Also, Charles Wright added that the newspaper also entertained people in the society to relieve stress.

Dennis McQuail, 2001,p 3 (McQuail, p 3, 2011) cited from Buaphuen Songyot, 2557 p. 82 said that another roles of newspaper was to mobilize the society to generate social changes. In democratic countries, mass media were flourished with freedom of expression. The media then became a double bladed sword as it could present facts and on the negative side, it could mislead people to violate the laws and orders.

Thailand has been pressured by many nations who would like to see our country move toward democracy, so mass media in Thailand has to play vital roles in developing democracy by providing information and knowledge, criticizing the government's performance, and mobilizing people to participate in democratic activities. However, some of the media agents work against the democratic principles for example Benjamin Ismail, a Director of Asia-Pacific Department, gave an interview to Matichon that "some media agents supported coup de tat. In fact, they have called for coup de tat for a while." (Benjamin Ismail, 2557 p. 26 a report on "Thailand: Effects of 2014 Coup de tat on Thai Mass Media). Also, Matichon online (4 ${ }^{\text {th }}$ February 2016) reported that Weera Sadomphug, chairman of the Federation of Radio and Television for the Development of Thai Business-the representative of Thai Radio Center, accompanied with the Thai Patriots Network of 77 Provinces announced at their office in Tak province that they would support and encourage Gen. Prayuth Chanocha in working for the nation even though the General had set up the government without general election.

Some groups of the mass media have no faith in election. Moreover, some believe that Thai people should not be allowed to have more freedom as they think that too much freedom has led Thailand to chaos. Some think "one man one vote" is not compatible with Thai society. Or some even believe that the government from the majority vote would lead to deconstruction of the nation. Additionally, some groups of the media had participated in the political movement that fought against the elected government. This revealed the political concepts that went against democracy. Some of the media also called for coup $d$ tat even though they deeply understood that the coup meant the use of military power to control the government. Mass media lost its freedom, and the newlyset government would not be monitored at all. This is what has happened in Thailand for the past decade. Accordingly, it is intriguing to learn which ideologies are influencing those groups of mass media to walk against the mainstream democracy. These media agents are causing the inconsistently development of Thai democracy. The study on "Ideology Dissemination that Caused Thai Mass Media to Have False Consciousness of Democracy" becomes a crucial issue to be researched. The objectives of the research are to study the definition of democracy coined in printed media and to study the ideology causing Thai mass media to have false consciousness in democracy. With the research question as follows: How did the academic works found in printed media coin the definition of democracy And Which ideology caused Thai mass media to have false consciousness in democracy.

The study on "Mass Media and Ideology Dissemination against Democracy in Thailand" is qualitative documentary study with the aim to research the definitions of democracy found in printed and electronic media that caused Thai mass media to have false consciousness against the principles of democracy.

Ideology means people's mindset and belief that are well accepted in the society, and able to reflect the social situation. They craft the people's thoughts and motivate the social movement in the desired directions. This study includes the following issueselection brings about bad politicians, the recruitment of good people to govern the nation, the promotion of supernatural belief, one man one vote is not for Thailand, capitalism deteriorates Thai community, and Armed forces work for the people.

Praise the elite: obey the "senior" who has morals and armed forces order people to obey. Mass media means people who work in editorial teams of newspapers, radio stations, local and central TV stations. Democratic principles includes sovereignty, freedom, equality, laws, and majority. False consciousness of democracy means the ideas or views that do not go in line with democratic principles. First, it is believed that election brings about bad politicians. This includes (1) the politicians win the election because they buy votes (2) the recruitment of good people 
to govern the nation; (3) the promotion of supernatural belief; (4) one man one vote is not for Thai community; (5) capitalism deteriorates Thai community; (6) and Armed forces work for the people. Second, Praise the elite: Obey the "senior" who has morals, and the Armed forces order the people to obey.

\section{Research methodology}

The study on "Mass Media and Ideology Dissemination against Democracy in Thailand" is qualitative documentary research with its details as follows:

\section{Documentary Research}

The research was a study of documents related to definitions of democracy and the ideology that caused Thai mass media to have consciousness that did not go in line with the democratic principles. The study was conducted through printed and other media related to the definitions of democracy, and the transmission of ideology to people through textbooks, books, text documents, newspapers, and other journals related to the definitions of democracy and the false consciousness of democracy.

The study on "Mass Media and Ideology Dissemination against Democracy in Thailand" will be presented in order as follows: Definitions of democracy, and Ideologies dissemination that do not go in line with democratic principles.

\section{Definitions of democracy}

From documentary research on the definitions of democracy, it revealed that the definition consisted of sovereignty, majority, equality, freedom, and principles of laws. It can be explained in a diagram as follows:

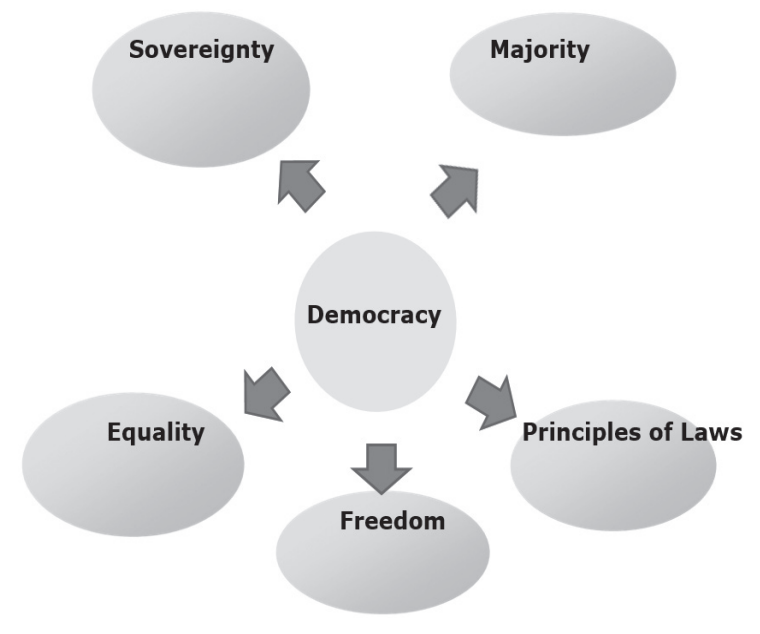

Figure 1.

Definition of Democracy
The diagram above revealed that the definition of democracy consisted of sovereignty, majority, equality, freedom, and principles of laws. Each concept could be explained as follows:

Likhit Theravakin (Theravakin, 2552: 12) stated that democracy meant the political system that the people took part in voting their representatives to govern the nation in Legislative Assembly, administrative council, and in some countries, the people were legitimated to elect judges. Accordingly, election was the symbol of democracy. However, only election could not be called "democracy" as the concept of democracy comprised basic rights and freedom especially physical right, right of expression, right to housing, right to travel and others. Democracy also covered equality which included equality before the laws--rich or poor people were under the same laws, and political equality which was the core concept of one man one vote-regardless of their wealth or properties, people had one vote each.

Preedee Kasemsap (2541: 11) said democracy came from "demos" and "kratos" which meant the power to govern the nation came from people. In English, it said government by consent. The government was elected and accepted by the people. The people gave their consent to the elected party to govern the nation. The consent did not mean that every single individual gave their consent to the same percept, but it meant the majority did.

\section{Ideologies dissemination that did not go in line with democratic principles}

The study on the Ideologies dissemination that did not go in line with democratic principles consisted of- 2.1 the election brings bad politicians, 2.2 the recruitment of good people to govern bad people, 2.3 the promotion of superstition, 2.4 one man one vote system did not suit Thai society, 2.5 capitalism deteriorated the nation, and 2.6 the Armed Forces worked for the people. It could be revealed in the Figure 2.

Diagram B in figure 2 revealed the Ideologies dissemination that did not go in line with democratic principles consisted of-2.1 the election brought bad politicians, 2.2 the recruitment of good people to govern bad people, 2.3 the promotion of superstition, 2.4 one man one vote system does not suit Thai society, 2.5 capitalism deteriorates the 
nation, and 2.6 the Armed Forces worked for the people.

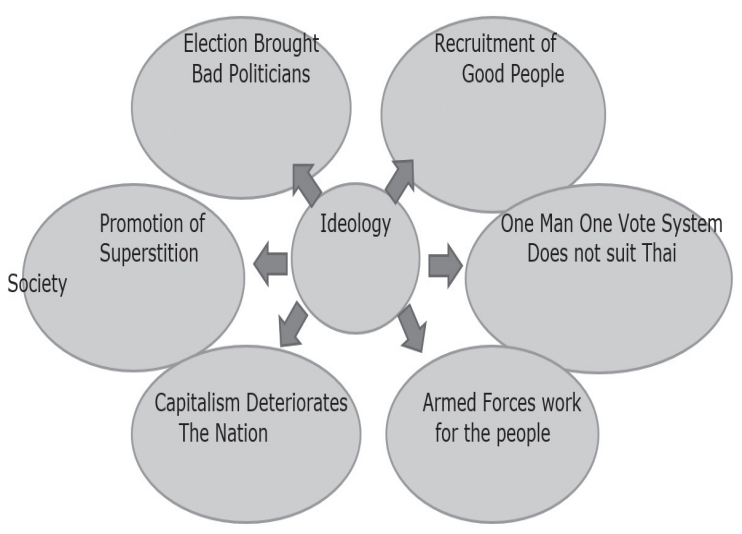

Figure 2.

Ideologies dissemination that do not go in line with democratic principles

\section{The election brought about bad politicians}

The study revealed that one of the ideologies disseminated in Thailand was "the election brought about bad politicians". Newspapers presented that the politicians won because they bought votes, and the recruitment of "good people" to govern the nation. They could be explained as follows: Vote buyers won the election. The study found that newspapers reported that a scholar -Sombat Thamrongthanyawong, a lecturer from NIDA said the politicians who won the election had bought votes. He said, "most of the representatives who won the election had bought vote. It meant that the election failed to find good people to govern the nation."

\section{The recruitment of good people to govern the nation}

The study found that on April 3, 2012 edition of Manger Newspaper and Manager website reported that the President of the Privy Council Gen. Prem Tinsulanonda had coined the terms "good people", and "bad people" as follows:

\section{"Good people"}

The newspaper reported that Gen. Prem Tinsulanonda had coined the term "good people" as (1) good people were those who had love of the nation, religion, and the King; (2) Good people were those who were loyal, devoted, and allegiant; (3) Good people, if they were leaders, they could be role models, kind, and equitable; (4) Good people were those who tried to demolish poverty; (5)
Good people followed the King's teachings; (6) Good people were those who worked worthily in terms of time, money, and self esteem; they were those who worked under the concepts of convenience, simplicity, and in the most economical ways; (7) Good people were those who preserved Thai culture, spoke with Thai dialects; good people were not crazed by Western cultures; (8) Good people, if they were senior citizen, they should take care and teach the younger ones and guide these young people to become good citizen of the nation; (9) Good people possessed morals.

\section{"Bad people"}

The study revealed that Gen. Prem Tinsulanonda had coined the term "bad people" as those who cheated the nation.

\section{Promotion of Superstition}

The study on the promotion of superstition revealed that the mass media reported news as follows:

Thairath online newspaper ( November 28, 2015) said, "Gen. Prem told Governors to teach children to be good citizen". Gen. Prem Tinsulanonda, the President of the Privy Council delivered this speech on the opening ceremony of the "San Jai Thai Soo Jai Tai-All Thais for the South" $14^{\text {th }}$ batch. His Excellency said in the Kingdom of Thailand good people had been protected by holy spirits. Phra Siam Dheva Dhiraj had protected the Thais regardless of their religions. The holy Phra Siam Dheva Dhiraj would curse those who did bad deeds to the nation. His Excellency Gen Prem said:

\begin{abstract}
"Phra Siam Dheva Dhiraj is holy and real. The Holy Siam Dheva Dhiraj has protected our Kingdom and every Thais who has done good deeds, and at the same time the Holy Siam Dehva Dhiraj would curse those who have done bad deeds. I hereby would like to request the Holy Siam Dheva Dhiraj to protect and bless us all to be auspicious."
\end{abstract}

Matichon Weekly, on its Nov27- Dec3, 2015 edition issue 1841 in the Column-"Summary of Domestic news" page 7, said, "Gen. Prem opened Anti Corruption Museum saying corruption was robbing the nation." Gen Prem said The Kingdom of Thailand had been protected by the Holy Siam Dheva Dhiraj which should be highly revered by all the Thais. His Excellency said:

"Our nation is holy. Those who cheat, and rob the nation have been seen by the Holy Siam Dheva Dhiraj, and all the past Kings. Don't be 
misunderstood that nobody sees."

Manager Online Newspapers on August 26, 2015 reported news about Gen. Prayuth Chan-Ocha, the Prime Minister. Gen. Prem, the President of the Privy Council made a wish on his $95^{\text {th }}$ birthday that His Excellency wished all the holy spirits would protect the Prime Ministers, all Ministers, and the Armed Forces. The Holy spirits would bless all the said parties to be the pillars of the nation. The newspaper said:

"Gen. Prem is a role model in devotion and work. His Excellency has worked and devoted himself to the nation. All the holy spirits will protect the Armed Forces to be the national Pillars."

\section{One man one vote is not suitable for Thai Society}

The study revealed that the scholars said, "one man one vote is not suitable for Thai society". The statement emphasized that, "One man one vote is not for Thai society as one vote of a Bangkok person has more quality than that of the rural voter." The newspaper reported as:

Siamturakij (May 22, 2015) reported that Prof. Sombat Thamrongthanyawong, former President of NIDA said, "One man one vote is not applicable for Thai society."

Saree Wongmontha, a mass communication scholar said one man one vote was not for Thai society as one vote from the rural area was not equal to the one from Bangkok. He said,

"300 thousand votes in Bangkok have better quality than 15 million votes from rural provinces."

However, some scholars disagreed with the above statements. Assoc, Prof. Nisit Phakawapan, a lecturer from the Faculty of Political Sciences, Chulalongkorn University, Asst. Prof. Yukti Mookdawichit, a lecturer from the faculty of Sociology and Anthropology, Thammasart University, and Asst. Prof. Aphichart Sathitniramai, a lecturer from the faculty of Economics, Thammasart University presented a research paper on "Re-Examining the Political Landscape of Thailand as Thailand was a patronage society (Sathitniramai, et al, 2013). Those who had no power would run to those who had power. The one without power would repay his or her patrons in different ways. The research summarized that the urban people strongly hold one discourse which led them to believe that the urban people were better educated, so they used their intelligence to vote, while those in other rural provinces were uneducated and had no clues of democracy. Accordingly, the votes from these rural provinces people had no quality unlike those of the Bangkokian voters'. It reads,

"Rural area is tightly related to patronage system. People run to those who have power in order to be under the patronage system. It's a vertical relationship. Thai society has been forced to believe so; however, the research group has not found such fact."

\section{Capitalism deteriorates the nation}

The study on the capitalism deteriorates the nation found in news reports as follows:

Chak Panchupeth (Panchupeth , 2548, p. 95) said the elite group consisted of people with conservative perceptions who disagreed with the moves towards capitalism. They wanted to preserve everything. So conservative ideology went against any changes as they believed that what had been passed on from generation to generation had already proven that they were good and suitable and should be continually practice.

\section{Armed Forces worked for the people}

The study on the armed forces worked for the people found that the newspapers reported the news as follows:

Banmuang newspaper (December 8, 2015) reported on its scoop that around the end of 2015, floods emerged in Thailand, and the Armed Forces helped the people and worked for the people. The news reported as:

\begin{abstract}
"A group of people who have never abandoned us since the very first minute of flood disasterthey have stood beside us without any tiresome or boredom. They are our soldiers. It is not only the duties of theirs that make the soldiers stand here for help, but also the belief that their breaths belonged to the people. With all their power, they would like to take care of the people of the country.
\end{abstract}

\section{Praising the Elite}

The study on praising the elite group revealed that the topic consisted of obeying the senior who have morals, and the elite group used power to lead the nation.

Obeying the senior who have morals; the study on "obeying the senior who have morals" revealed that the newspapers reported news as follows: 
Matichon (November 23, 2015) reported that Prof. Kasern Techapira, the lecturer from the Faculty of Political Sciences, Thammasart University said, "the elite group will guide the people to accept what the senior citizen in Thai society say. It is the traditional power of the elite noblemen. The elite in Thailand claims that the power they have has been passed on, and cannot be checked and questioned. Thai people must follow."

Manager newspaper (April 26, 2008) reported that Gen. Aupong Phaochinda, Thai Army Commander, said Gen Prem Tinsulanonda was a real statesman. He should be praised and revered by the whole society. It reads:

\begin{abstract}
"We have praised Gen. Prem as a statesman. His work and what he has done to the nation actually should be acknowledged and praised in the society."
\end{abstract}

The Armed Forces use Power to Force people; the study on the Armed Forces use power to make people obey showed the newspapers reports as follows:

On Matichon Newspaper (December $15,2014)$ in the column-"Krasatas" written by Prof. Nithi Aiew-Sriwong, it said the elite group in Thailand used its power to govern Thailand through public units, armed forces, official systems, communicative devices etc. It is the absolute power. One example is the seizure of the elected government power by the National Council for Peace and Order. It was the use of Armed forces to make other sections to surrender. The newspaper read:

\begin{abstract}
"Since the first day of the seizure of the government power, the National Council for Peace and Order has used the power of the Armed Forces to make people surrender. Sometimes, it became the use of heavy weapons to drive out unarmed people who gather to fight against the coup. Still the armed forced were used to arrest protesters and capture people in a military camp for attitude adjustment.
\end{abstract}

\section{Discussion}

The study on "Mass Media and Ideology Dissemination against Democracy in Thailand" could be discussed as follows:

First. the study found that "democracy" consisted of 5 concepts: sovereignty, majority, equality, freedom, and principles of laws. However, some mass media in Thailand gained false consciousness toward democracy as the elite groups who had power in Thai society did not pay attention on promoting democracy. The communism stated that the elite group disseminated 6 ideologies that went against democracy to Thai people. The said 6 ideologies were election brought bad politicians; one man one vote was not for Thailand as one vote from the rural areas was not as qualified as the one from Bangkok. It came with the belief that people in Bangkok were more educated and paid higher taxes.

Accordingly, in Thai circumstances, the elite group believed that the recruitment of administrators was more suitable than election. If not so, they thought the armed forces set coup de tat and governed the nation was still better than election because the Armed Forces worked for the people. This was much better than administrating the nation with the concept of capitalism which deteriorated the nation. They believed capitalism was not in line with sufficient economy. In addition, the elite group in Thailand promoted the belief of superstition which obstructed the development of democracy and sciences in Thailand.

Now, the definition of democracy was the administrative system that gave the power of sovereignty to the people. It came with the belief that humans were reasoned, intellectual. Equipped with right and freedom in searching for information to support their judgment, people were able to use their intellectual abilities in selecting what was good and right for them. In conclusion, "good citizen" in democracy should not be an individual who believed in superstition and holy power of Phra Siam Dheva Dhiraj. They should be people who had reason and could make their own judgment based on factual information.

This result was in accordance with Iyep Saefulrahman's (Saefulrahman, 2016) study on "Two Democratic tradition in the Election of Head The Village in Neglasari, Tasikmalaya." The result showed that things had gone through many changes, the tradition still worked effectively in village democracy, especially in the election o head of village. While many countries supported one man one vote of election system, but political situation in Thailand, the conservative elites never supported one man one vote with reason as one vote from the rural areas was not as qualified as the one from Bangkok.

"Good Citizen" should not be the ones who believed in superstition. "Good Citizen" should be the ones who respected their own rights and other people's right. They should fight for the equality of people in the society and try to erase gaps among people. This 
meant they tried to reduce conflicts in the society which was much more important than the tie of superstition. If the leaders of the nation wanted to give freedom and rights to the people they should not define "good Citizen" as those who obey them. They should allow the people to have freedom and rights to search for information and use the intellectual ability to make judgment. Also, they should open to those who think differently.

Then, Second. The study on the ideology saying election brought bad. Politicians stated that the politicians bought votes and committed the election fraud. Moreover, the urban people believed that rural people were uneducated and had no clue of democracy. This was in accordance with Prof. Anake Laothammathat's study, a scholar from the faculty of Political Sciences, Thammasart University. He wrote in his book, A Tale of Two Democracies, that the conflict between the rural and the urban cities had been emerged for ages (Laothammathat, 2013). The rural people supported the government whose stronghold was in the rural areas. They won the election and formed the government; however, after a short while of administration, the elite and bourgeois groups in Bangkok eliminated the elected government by using mass media as a tool to mobilize people to fight against the government. The ideology stated the election bought bad politicians, so the better path to get good people to govern the nation was the recruitment of good administrators.

However, Kasem Penpinan, a lecturer of philosophy, faculty of Arts, Chulalongkorn University, said the statement of good people or bad people coined by the elite group was not related to democracy because "goodness" and "democracy" were different subjects. Kasem criticized that the elite group obstructed some politicians to administrate the nation by claiming that these politicians were bad; thus, they should not rule the nation even though they came from political election. This was in line with the writing, " A Stone Pillar in a Strong Tide" by Mookda Suwannachart, on Matichon Weekly September 16-22, 2016 Edition. It said the elite groups made Thai media accept coup de tat, and supported the coup to stay in power as long as possible. The media who supported the democracy was just a minority.

This study was in accordance with Hanny Hafiar, Yanti Setinti's study (Hafiar and Setinti, 2016). The study of optimization of report regarding the activity of people with disability in media showed that mass media neglected reporting some events and online media were more flexible than printed media and broadcast media, that meant some events disappeared in broadcast media and printed media, but appeared in online media and mass media neglected report community's news. The research result showed that mass media in Thailand gave priority to the privy councilor, Prem Tinsulanonda to speak and talk to the public while other classes especially the grass roots had no chance to speak at all.

After that, Three. the study on the ideology on the promotion of superstition found that the ideology stated that the Kingdom of Thailand and those who did good deeds were protected by holy spirits, and the spirits would terminate those who did bad deeds. It was in accordance with Suwit Maprasong's study (Maprasong, 2012) on the Belief of Holy Spirits in the Dynamic Contexts and the Local People's Relationship Adjustment. It said social institutes implanted the ideology to superstition and holy spirits. The holy spirits would destroy bad people and protect the good people from all the dangers.

Kasean Tachapeera (2012) criticized, the President of the Privy Council, Gen Prem Tinsulanonda's speech delivered on the $12^{\text {th }}$ anniversary of the Office of the Ombudsman at United Nations Conference Center. Gen Prem said," I truly believe that Phra Siam Dheva Dhiraj protects good people and curses bad people who cheat the nation. This is what I believe. It depends on morals and ethics of each individual whether he or she believes in the holy Phra Siam Dheva Dhiraj. Kasean then said this statement tied the holy Siam Dheva Dhiraj, the Royal Nationalist Palladium with ethics. First, ethics and morals which should be individually possessed were tied with the nation; hence, conducting good deeds was not individually anymore. It became a part of the Royal Nationalist Palladium. Second, people who were flourished with ethics and morals must be those who engaged themselves with the benefits of the nation only. Prof. Kasean added whether it was right if someone lied for the nation or eliminated other people for the national benefits. He also questioned that being good citizen meant you were a part of Royal Nationalist Palladium. Apart from this concept, you were not considered good.

And the last is Four. the study on the ideology that said capitalism deteriorated the nation found that some mass media believed 
that the development in democratic practices resulted in negative impact on Thai society. This was in accordance with Phumiwat Nukit's statement which said the conservative Thais consisted of some noblemen, leaders from Armed Forces, mass media, political parties, and some businesses that were privileged. With all these aids from the above mentioned bodies, the development of democracy in Thailand went unsteadily. This was also in line with, an activist, Rungsiman Roam's view which believed that Thai society was forced to hate those who supported democracy. (Matichon newspaper September 19, 2016). Thailand had never built up political cultures for democracy. Thai society had never supported the concepts of exchange of ideas. In Thailand it was prohibited to think differently. (Matichon newspaper September 19, 2016 on the column-A Decade of Coup De tat on September 19, 2006-A Decade of Misstep, an interview with Chatuphat Boonpattararaksa or Phai Dao Din). Moreover, this study got in line with a democratic activist, Sombat Boon-ngam-anong's saying. He said the elite group had implanted the idea that democracy was not right for Thai people, so many Thai people were disseminated with false consciousness of democracy, and many more people were fighting against democracy.

\section{Conclusions}

Some mass media agents in Thailand support conservative elite group. The disseminate ideologies did not go in line with democratic principles. Some of the mass media choose to report opinions of those wellknown academic people. The reports become abused principle according to their bias. For example, they reported that the election brought bad politicians, so the system "One Man One Vote" was not suitable for Thailand. They also reported that the politicians from the election will be corrupt. The better way was recruitment from those who claim themselves "Good people" - people who were loyal, devoted, allegiant, and those who followed the King's teachings, reserved Thai culture, spoke with Thai dialects: and were not crazed by Western cultures and possessed morals. These are more important than anything. The media report that armed forces could govern the nation better than the opposite politicians with the belief that the armed forces work for the people. However, there were some academic critics that the definitions of good people or bad people were coined by the elite group only. It was not related to democracy because goodness and democracy were the different subject.

\section{References}

Arnold S.De beer. and John C. Merrill. (2011). Global Jounalism, Topical Issues and Media Systems. Pearson. USA.

Eugenia Siapera. (2011). Cultural Diversity and Global Media.The Mediation of Difference. A John Wiley \& Sons, Ltd, Publication.

Gramsci, Antonio (1971). Selections from the Prison Notebooks.International Publishers.

Hafiar, H., and Yanti Setinti. (2016). Optimization of report regarding the activity of people with disability in media. MIMBAR Jurnal Sosial dan Pembangunan.Volume 32, No. 1

Jane Stokes. (2013). Historical Journal of Film, Radio and Television. Routledge

Jane Stokes.(2013). How to Do Media and Cultural Studies. Sage Publication.

Laothammathat, A. (2013). A Tale of Two Democracies: $8^{\text {th }}$ edition. Bangkok. Kopfai Publisher.

Manager Online (August 26, 2015)

Maprasong, S. (2012). Out of the fire, December 5, 2015 http://library thaihealth.or.th.

Matichon (December 15, 2014)

Matichon (December 16, 2014)

Matichon Weekly (December 27-3, 2015)

Matichon Weekly (September 16-22, 2016 36 issue 1883)

Mattelart, A., and Michele Mattelart.(1998). Theories of Communication. A Short Introduction. Sage Publication.

McQuail, D.(2001). Mass Communication Theory.Sage Publication.

Panchopeth, C. (2005). Political Sciences. Pathumthani. Punch Group Publication.

Saefulrahman, I. (2016).Two Democratic tradition in the Election of Head The Village in Neglasari, Tasikmalaya. MIMBAR Jurnal Sosial dan Pembangunan.Volume 32, No.2.

Sathitniramai, A., Yukti Mookdawichit, and Niti pakawatpan. (2013). The Review of Thailand Political Landscape. Bangkok

Thairath (November 28, 2015)

Theravakin, L.(2009). Thai Politics and Democracy. Mister Copy (Thailand) Ltd Bangkok.

Xioling Zhang.2013). The Transformation of Political Communication in China. From Propaganda to Hegemony. World Scientific Publishing Co. PTE.Ltd. 